\title{
Blockade of Toll-Like Receptor 4 Attenuates Morphine Tolerance and Facilitates the Pain Relieving Properties of Morphine
}

\author{
Lori N. Eidson and Anne Z. Murphy \\ Neuroscience Institute, Georgia State University, Atlanta, Georgia 30303
}

The ventrolateral periaqueductal gray (vlPAG) is an integral locus for morphine action. Although it is clear that glia contribute to the development of morphine tolerance, to date, the investigation of their role has been limited to spinal and medullary loci. Opioids induce a neuroinflammatory response that opposes acute and long-term analgesia, thereby limiting their efficacy as therapeutic agents. Recent data suggest that the innate immune receptor Toll-like receptor 4 (TLR4), along with its coreceptor myeloid differentiation factor-2 (MD-2), mediates these effects. To date, the brain loci through which TLR4 modulates morphine tolerance have not been identified. We have previously demonstrated that chronic subcutaneous morphine results in tolerance that is accompanied by increases in vlPAG glial cell activity. Using in vivo pharmacological manipulations of vlPAG glia and TLR4 in the adult male rat, we show that intra-vlPAG administration of the general glial cell metabolic inhibitor propentofylline or the astrocyte activity inhibitor fluorocitrate attenuate tolerance to morphine. Characterization of MD-2 expression within the PAG revealed dense MD-2 expression throughout the vlPAG. Further, antagonizing vlPAG TLR4 dose dependently prevented the development of morphine tolerance, and vlPAG microinjections of TLR4 agonists dose dependently produced a "naive" tolerance to subsequent challenge doses of morphine. Finally, using a model of persistent inflammatory pain and pharmacological manipulation of TLR4 we demonstrate that systemic antagonism of TLR4 potentiated acute morphine antihyperalgesia. These results, together, indicate that vlPAG glia regulate morphine tolerance development via TLR4 signaling, and implicate TLR4 as a potential therapeutic target for the treatment of pain.

\section{Introduction}

Opioids remain an integral part of clinical pain management (Trescot et al., 2008). However, acute and chronic morphine induces a CNS proinflammatory glial response that actively opposes the analgesic effects of morphine and contributes to the development of tolerance (Song and Zhao, 2001; Eidson and Murphy, 2013). Morphine-induced neuroinflammation is evidenced by increases in spinal microglia and astrocyte activity markers OX-42 and glial fibrillary acidic protein (GFAP), respectively. Release of glially derived proinflammatory cytokines, hallmarks of neuroinflammation, is also induced by morphine (Hutchinson et al., 2009). Intrathecal glia inhibitors (e.g., propentofylline) decrease morphine-induced cytokine release and attenuate morphine tolerance (Song and Zhao, 2001; Cui et al., 2008). Similarly, blockade of spinal cytokine action attenuates

Received April 16, 2013; revised Aug. 26, 2013; accepted Aug. 27, 2013.

Author contributions: L.N.E. and A.Z.M. designed research; L.N.E. performed research; L.N.E. and A.Z.M. analyzed data; L.N.E. and A.Z.M. wrote the paper.

National Institutes of Health Grant DA16272 awarded to A.Z.M. supported this work. (-)-Morphine sulfate, $(+)$-morphine, and $(+)$-naloxone were kindly provided by the National Institute on Drug Abuse drug supply program.

The authors declare no competing financial interests.

Correspondence should be addressed to Dr. Anne Z. Murphy, Neuroscience Institute, Georgia State University, 100 Piedmont Avenue, Atlanta, GA 30303. E-mail: amurphy@gsu.edu.

DOI:10.1523/JNEUROSCI.1609-13.2013

Copyright $\odot 2013$ the authors $\quad 0270-6474 / 13 / 3315952-12 \$ 15.00 / 0$ tolerance, indicating that CNS glia modulate morphine action (Raghavendra et al., 2002; Hutchinson et al., 2008a).

Opioids, including morphine, bind to myeloid differentiation factor-2 (MD-2) of the innate immune receptor Toll-like receptor 4 (TLR4), leading to initiation of the TLR4 signaling cascade that results in a proinflammatory response (Hutchinson et al., 2010a; Lewis et al., 2010). TLR4 is found primarily on microglia, and to a lesser degree on astrocytes (Lehnardt et al., 2003; Jou et al., 2006). Spinal TLR4 activity opposes the acute effects of morphine, including antinociception, and contributes to opioidinduced hyperalgesia (Hutchinson et al., 2010b; Lewis et al., 2010). Unlike classical opioid receptors, which only bind the $(-)$-stereoisomer of opioids, TLR4 binds opioids in a nonstereoselective fashion with both $(-)$ - and $(+)$-ligands affecting the signaling cascade and modulating opioid analgesia (Hutchinson et al., 2010b). Indeed, (+)-morphine decreases acute intrathecal (-)-morphine analgesia (Terashvili et al., 2007). Similarly, in vitro studies show that both $(-)$ and $(+)$-naloxone block $(-)$ morphine-induced TLR4 activation (Hutchinson et al., 2010b). Although systemic antagonism of TLR4 prevents the development of tolerance to systemic morphine, the brain loci through which TLR4 mediates morphine tolerance have not been investigated (Hutchinson et al., 2010b).

The periaqueductal gray (PAG), and its descending projections to the rostral ventromedial medulla and spinal cord, comprise an essential neural circuit for opioid-mediated analgesia (Basbaum et al., 1978). Tolerance is quick to develop following 
repeated administration of morphine into the ventrolateral PAG (vlPAG) (Morgan et al., 2006a). Blocking opioid binding in the vlPAG with the antagonist naltrexone significantly attenuates the development of tolerance to systemically administered morphine, indicating that key mechanisms underlying morphine tolerance are localized in the vlPAG (Lane et al., 2005).

Although it is clear that CNS activation of glia contributes to the development of morphine tolerance, no studies to date have examined the role of activated glia within the PAG, despite extensive evidence indicating its importance for morphine action (Tortorici et al., 2001; Morgan et al., 2006a; Loyd et al., 2008a).

Here we tested the hypothesis that vlPAG glia activation contributes to morphine tolerance development through action at TLR4. As morphine is primarily consumed for the alleviation of severe pain, in our final experiments we used an animal model of persistent inflammatory pain to test the hypothesis that TLR4 blockade would enhance the antihyperalgesic effects of acute morphine.

\section{Materials and Methods}

Subjects

Weight-matched (250-350 g) male Sprague Dawley rats (Charles River) were pair-housed on a $12 \mathrm{~h}$ light/dark cycle (lights on a 7:00 A.M.). Access to food and water was available ad libitum throughout the experiments except during behavioral testing. All studies were approved by the Institutional Animal Care and Use Committee at Georgia State University, and performed in strict compliance with Ethical Issues of the International Association for the Study of Pain and National Institutes of Health. All efforts were made to reduce the number of animals used in these experiments and to minimize any possible suffering by the animal.

\section{Intra-vlPAG cannulae implantation}

Animals in Experiments 1, 2.2, and 2.3 were anesthetized to a deep surgical plane with $5 \%$ isoflurane (Baxter Healthcare) and maintained at $2-5 \%$ isoflurane throughout surgery. Animals were implanted with bilateral guide cannulae (22 gauge; Plastics One) aimed at the vlPAG (anterior-posterior: $1.7 \mathrm{~mm}$, mediolateral: $\pm 0.6 \mathrm{~mm}$, dorsoventral: -5.0 $\mathrm{mm}$ from lambda) using stereotaxic techniques as previously described (Loyd et al., 2008b). Skull screws and dental acrylic were applied to hold cannulae securely in place. Skin staples were used to close the site, and animals were given $0.05 \mathrm{ml}$ of Baytril subcutaneously to prevent infection. Injection cannulae were inserted into guide cannulae once every $24 \mathrm{~h}$ to acclimate the animals to the injection procedure and maintain cannulae patency. As repeated insertion of the injection cannulae has the potential to cause tissue damage-induced glial activation, we compared OX-42 and GFAP staining levels in the vlPAG for animals treated with vlPAG saline and animals that were treated with subcutaneous saline (Eidson and Murphy, 2013) and found no differences in expression (data not shown).

Experiment 1.1: influence of vlPAG glial cell activation on morphine tolerance development

Following recovery from cannulae implantation (1 week) animals were given morphine $(5 \mathrm{mg} / \mathrm{kg}$, s.c.; National Institute on Drug Abuse (NIDA), Bethesda, MD) once a day for $3 \mathrm{~d}$ to induce behavioral tolerance to challenge doses of morphine. The $5 \mathrm{mg} / \mathrm{kg}$ dose was chosen based on our previous studies demonstrating this to be the $50 \%$ effective dose $\left(\mathrm{ED}_{50}\right)$ for systemic morphine in male rats (Wang et al., 2006; Morgan et al., 2006b; Loyd et al., 2007). The time course of morphine injection was chosen based on our previous data demonstrating this to be sufficient for the induction of morphine tolerance (Loyd et al., 2008a; Eidson and Murphy, 2013). Control animals received sterile saline (1 ml/kg; s.c.) once a day for $3 \mathrm{~d}$.

Glial inhibition. Separate groups of animals were treated with one of three glia inhibitors: the general glial cell inhibitor propentofylline (10 fmol or $100 \mathrm{fmol}$; Sigma), the microglia inhibitor minocycline $(10 \mathrm{fmol}$, 1 pmol, or 10 pmol; Sigma), or the astrocyte inhibitor fluorocitrate (1 fmol or 10 pmol; Sigma). Glia inhibitors were administered 16 and $1 \mathrm{~h}$ before the first morphine injection and $30 \mathrm{~min}$ before the last two morphine injections based on the injection protocols of Cui, Wei, and Tawfik et al. (Tawfik et al., 2007; Cui et al., 2008; Wei et al., 2008). Previous studies suggest that preemptive doses (i.e., the 16 and $1 \mathrm{~h}$ doses) of these inhibitors are necessary to counteract morphine-induced glial cell activation (Tawfik et al., 2007; Wei et al., 2008). The 30 min time point was chosen based on previous work using minocycline (Cui et al., 2008). All doses were chosen based on intracranial doses known to affect glia without affecting neurons, and known to have no effect on the microglia and astrocyte activity of naive animals (Wei et al., 2008). All drugs were administered bilaterally $(0.25 \mu \mathrm{l} / \mathrm{side} / 2 \mathrm{~min})$. Control animals received intra-vlPAG microinjections of vehicle (sterile saline; $0.25 \mu \mathrm{l} /$ side). Microinjections were slowly infused through a $5 \mu \mathrm{l}$ Hamilton syringe at a rate of $0.125 \mu \mathrm{l} / \mathrm{min}$ using a Harvard Apparatus 11 Plus syringe pump to allow for diffusion of the drug and to minimize tissue damage. Injection cannulae were left in place for $60 \mathrm{~s}$ following the microinjections to prevent backflow upon removal.

Morphine challenge. Tolerance was assessed on day 5 (day 1 being the first day of vlPAG microinfusions) by injecting cumulative doses of morphine every $20 \mathrm{~min}$, resulting in doses of 3.2, 5.6, 8.0, and $10.0 \mathrm{mg} / \mathrm{kg}$ subcutaneously as previously described (Loyd et al., 2008a; Eidson and Murphy, 2013). Nociception was assessed using the paw thermal stimulator 15 min after each injection (Hargreaves et al., 1988; Wang et al., 2006). Briefly, for this test, the rat is placed in a clear Plexiglas box resting on an elevated glass plate maintained at $30^{\circ} \mathrm{C}$. A radiant beam of light is positioned under the hindpaw and the time for the rat to remove the paw from the thermal stimulus is electronically recorded as the paw withdrawal latency (PWL). A maximal PWL of $20.48 \mathrm{~s}$ was used to prevent excess tissue damage due to repeated application of the noxious thermal stimulus. Animals were acclimated to the testing apparatus (30 min a day for 3 consecutive days) at the start of the experiment. All behavioral testing took place between 12:00 and 5:00 P.M. (lights on at 7:00 A.M.). All testing was conducted blind with respect to group assignment.

Data analysis and presentation. PWLs are measured in seconds and the half-maximal antinociceptive effect $\left(D_{50}\right)$ and $95 \%$ confidence intervals (CI) were calculated from dose-response curves generated using GraphPad software (Loyd et al., 2008a; Bobeck et al., 2012). The lower limit for calculating $\mathrm{D}_{50}$ values was the mean baseline score, and the upper limit was the mean PWL following administration of the highest morphine dose. Changes in $\mathrm{D}_{50}$ between groups were assessed using ANOVA, and Fisher's post hoc tests were used to determine specific group differences when a significant main effect was observed. All values are reported as mean $\mathrm{D}_{50} \pm 95 \% \mathrm{CI} ; p \leq 0.050$ was considered significant.

\section{Experiment 1.2: anatomical assessment of vlPAG glial cell inhibition}

One hour following tolerance assessment, animals were given a lethal dose of Nembutal (160 mg/kg; i.p.) and transcardially perfused with 250 $\mathrm{ml}$ of $0.9 \%$ sodium chloride containing $2 \%$ sodium nitrite as a vasodilator to remove blood from the brain. Immediately following blood removal, $300 \mathrm{ml}$ of $4 \%$ paraformaldehyde in $0.1 \mathrm{M}$ phosphate buffer containing $2.5 \%$ acrolein (Polysciences) was perfused through the brain as a fixative. A final rinse with $250 \mathrm{ml}$ of sodium chloride/sodium nitrite solution was perfused through the brain to remove any residual acrolein. Brains were removed and placed in a $30 \%$ sucrose solution and stored at $4^{\circ} \mathrm{C}$ until sectioning.

Cannulae placement verification. Perfusion fixed brains were sectioned into $25 \mu \mathrm{m}$ coronal sections with a Leica 2000R freezing microtome and stored free floating in cryoprotectant-antifreeze solution at $-20^{\circ} \mathrm{C}$. A $1: 6$ series through the rostrocaudal axis of each brain was Nissl stained, coverslipped, and cannulae placement was verified visually using a Nikon microscope (10× magnification). Animals with bilateral cannulae located outside of the vlPAG (e.g., deep mesencephalic nucleus, DpMe) were considered "cannulae misses" and were included for analysis for site specificity.

Immunohistochemistry. As a positive control that propentofylline, minocycline, and fluorocitrate inhibited microglia and astrocyte activity, immunoreactivity of vlPAG glial cell activity markers was analyzed. Hallmarks of glial cell activity include increased cytokine release that corre- 
lates with increased expression of the protein markers CD-11b (OX-42; microglia) and GFAP (astrocytes; Raghavendra et al., 2002). Further, increased glial cell activity is evidenced by a profound shift in morphology that can be easily visualized using immunohistochemistry for OX-42 and GFAP (Colburn et al., 1999). Perfused brains were sectioned into 25 $\mu \mathrm{m}$ coronal sections with a Leica 2000R freezing microtome and stored free floating in cryoprotectant-antifreeze solution (Lewis et al., 1986) at $-20^{\circ} \mathrm{C}$. A 1:6 series through the rostrocaudal axis of each brain was processed for OX-42 and GFAP immunoreactivity using standard immunohistochemical techniques (Murphy and Hoffman, 2001). Briefly, sections were rinsed extensively in potassium PBS (KPBS) immediately followed by a $20 \mathrm{~min}$ incubation in $1 \%$ sodium borohydride. The tissue was then incubated in primary antibody solution (mouse anti-CD11b (OX-42) 1:3000, Serotec; or rabbit anti-GFAP 1:5000; Abcam) in KPBS containing 1.0\% Triton-X for $1 \mathrm{~h}$ at room temperature followed by $48 \mathrm{~h}$ at $4^{\circ} \mathrm{C}$. After rinsing with $\mathrm{KPBS}$, the tissue was incubated for $1 \mathrm{~h}$ in secondary antibody (biotinylated IgG goat anti-mouse or anti-rabbit; 1:600; Jackson ImmunoResearch), rinsed with KPBS, and then incubated for $1 \mathrm{~h}$ in an avidin-biotin peroxidase complex (1:10; ABC Elite Kit; Vector Laboratories). After rinsing in KPBS and sodium acetate $(0.175 \mathrm{M}$, $\mathrm{pH}$ 6.5), OX-42 or GFAP immunoreactivity was visualized as a black reaction product using nickel sulfate intensified $3,3^{\prime}$-diaminobenzidine solution $(2 \mathrm{mg} / 10 \mathrm{ml})$ containing $0.08 \%$ hydrogen peroxide in sodium acetate buffer. After $15 \mathrm{~min}$, tissue was rinsed in sodium acetate buffer followed by KPBS. Following secondary incubation, sections were rinsed in KPBS. Sections were mounted out of KPBS onto gelatin-subbed slides, air-dried, and dehydrated in a series of graded alcohols. Tissue-mounted slides were then cleared in xylenes and glass coverslipped using Permount.

Anatomical data analysis and presentation. Levels of OX-42 and GFAP immunoreactivity in the vlPAG were compared across treatment groups using semiquantitative densitometry as previously described (Loyd et al., 2008a; LaPrairie and Murphy, 2009; Eidson and Murphy, 2013). Twelvebit grayscale images that included the region of interest (ROI) were captured using QImaging Retiga EXi CCD camera attached to a Nikon microscope and iVision Image analysis software (BioVision Technologies). Grayscale values for each image were inverted so that higher values were representative of increased staining levels. Images of three slices through each ROI for each animal were analyzed and data sampled unilaterally. Data sampling occurred by using the drawing tools in iVision to outline the ROI and using the "measure" function to determine an average grayscale pixel value for the outlined area. ROI measures were corrected for nonspecific binding by subtraction of background measure taken from gray matter adjacent to the ROI. Data were analyzed across three representative levels through the rostrocaudal axis of the vlPAG (bregma $-7.08,-7.68$, and -8.30 ) as previously described (Paxinos and Watson, 1977; Loyd et al., 2008a). Densitometry values are presented as the mean \pm SEM density of immunoreactivity. Data were analyzed using an ANOVA to determine significant main effects of treatment. Fisher's post hoc tests were used to determine specific group differences when a significant main effect was observed; $p \leq 0.050$ was considered statistically significant.

Experiment 2: modulation of morphine tolerance by vlPAG TLR4 The TLR4/MD-2 complex binds opioids including morphine and mediates glial cell activation (Hutchinson et al., 2007, 2010b; Watkins et al., 2009; Lewis et al., 2010). While TLR4 signaling has been implicated in glially mediated morphine opposition, the specific role of TLR4 activation in the development of morphine tolerance is largely unknown. Our overarching hypothesis is that morphine activation of TLR4 within the vlPAG is a primary mechanism underlying the development of tolerance.

Experiment 2.1: myeloid differentiation factor-2 expression within the PAG

Normal male Sprague Dawley rats were perfused as described above. A 1:6 series through the rostrocaudal axis (bregma $-6.72,-7.08,-7.68$, $-8.04,-8.28$, and -8.76 ) of the PAG was processed for immunohistochemical labeling of MD-2 as a positive control for the presence of the MD-2/TLR4 complex. Both the dorsolateral (dlPAG) and vlPAG were examined. The dlPAG (bregma $-6.72,-7.08,-7.68$, and -8.04 ) was included as this region is virtually devoid of the mu opioid receptor (MOR), expresses very little morphine-induced Fos, and has not been implicated in morphine tolerance development (Tortorici et al., 1999; Loyd et al., 2007). Immunohistochemistry is as described above with the exception of the primary (rabbit anti-MD-2 primary antibody, 1:200; Abcam) and secondary (biotinylated IgG goat anti-rabbit secondary, 1:600; Jackson ImmunoResearch) antibodies. Twelve-bit grayscale images that included the ROI were captured using a QImaging Retiga EXi CCD camera and iVision Image analysis software to visualize MD-2 expression within the PAG. Anatomical data analysis and presentation are as described above, except here we sampled two sections per animal per bregma level.

\section{Experiment 2.2: necessity of vlPAG TLR4 in morphine} tolerance development

Following recovery from cannulae implantation (1 week) animals were given morphine ( $5 \mathrm{mg} / \mathrm{kg}$; s.c.; NIDA) once a day for 3 consecutive days to induce behavioral tolerance to a challenge dose of morphine. Control animals received saline ( $1 \mathrm{ml} / \mathrm{kg}$; s.c.) once a day for 3 consecutive days. Immediately following subcutaneous injections, animals received bilateral intra-vlPAG microinjections of the competitive TLR4 antagonist LPS-RS $(1.7 \mu \mathrm{g}$ or $2.4 \mu \mathrm{g} / 0.5 \mu \mathrm{l} / \mathrm{side}$; InvivoGen), the stereoselective TLR4 antagonist (+)-naloxone ( $5 \mu \mathrm{g} / 0.5 \mu \mathrm{l} /$ side; NIDA), or saline $(0.5$ $\mu \mathrm{l} /$ side; as a vehicle control). Lipopolysaccharide produced by Rhodobacter sphaeroides (LPS-RS) was chosen as a TLR4 antagonist as it has been shown to competitively bind to TLR4, enhance morphine analgesia, prevent release of cytokines, and block the morphine-induced TLR4 signaling cascade (Watkins et al., 2009). The LPS-RS dose was chosen based on intracranial LPS doses, and the fact that LPS and LPS-RS are typically administered at the same dose (Castaño et al., 2002; Hernández-Romero et al., 2008; Santiago et al., 2009; Mauriño et al., 2010; Hutchinson et al., 2010b). (+)-Naloxone was chosen as this TLR4 antagonist readily crosses the blood-brain barrier, and has been shown to enhance morphine analgesia and block the morphine-induced TLR4 signaling cascade (Watkins et al., 2009; Hutchinson et al., 2010b; Lewis et al., 2012). The $(+)$-naloxone dose was chosen based on intra-PAG doses of $(-)$ naloxone and the fact that $(-)$ - and $(+)$-naloxone block $(-)$-morphineinduced TLR4 signaling to a similar degree, and on a similar time course (Hammer and Kapp, 1986; Hutchinson et al., 2010b). Tolerance assessment took place $24 \mathrm{~h}$ following $3 \mathrm{~d}$ of drug administration as described above. Briefly, animals were given cumulative doses of subcutaneous morphine in the absence of intra-vlPAG microinjections and PWLs were measured in response to a noxious thermal stimulus. Following tolerance assessment animals were perfused and brains removed and sectioned for visualization of cannulae location. To determine site specificity, animals with bilateral cannulae located outside of the vlPAG (e.g., DpMe) were included in the analysis. Data analysis and presentation are as described above.

\section{Experiment 2.3: sufficiency of vlPAG TLR4 activation to induce} naive tolerance to morphine

Experimental methods are identical to Experiment 2.2. To test for the sufficiency of vlPAG TLR4 to induce tolerance, a separate group of animals received bilateral intra-vlPAG injections of the prototypical TLR4 agonist LPS ( $1.7 \mu \mathrm{g}$ or $5 \mu \mathrm{g} / 0.5 \mu \mathrm{l} /$ side; Sigma), the TLR4 agonist KDO2 $(0.5 \mu \mathrm{g}, 1 \mu \mathrm{g}$, or $5 \mu \mathrm{g} / 0.5 \mu \mathrm{l} / \mathrm{side}$; Avanti Polar Lipids), the stereoselective TLR4 agonist (+)-morphine ( $5 \mu \mathrm{g} / 0.5 \mu \mathrm{l} /$ side; NIDA), or vehicle control (saline; $0.5 \mu 1 /$ side) once a day for 3 consecutive days. Animals in this experiment did not receive subcutaneous (-)-morphine until the final testing day (morphine challenge). LPS is a prototypical TLR4 agonist and has been shown to competitively bind to TLR4, resulting in the production of cytokines, and attenuation of acute morphine analgesia (Hutchinson et al., 2010b). The chosen LPS dose was based on intracranial LPS doses that are sufficient to induce glial activation and cytokine expression (Castaño et al., 2002; Hernández-Romero et al., 2008; Santiago et al., 2009; Mauriño et al., 2010). Similar doses of KDO2-Lipid A were chosen because KDO2 is a substructure of LPS with endotoxin activity that is equal to that of native LPS. Finally, the $(+)$-morphine dose 
a

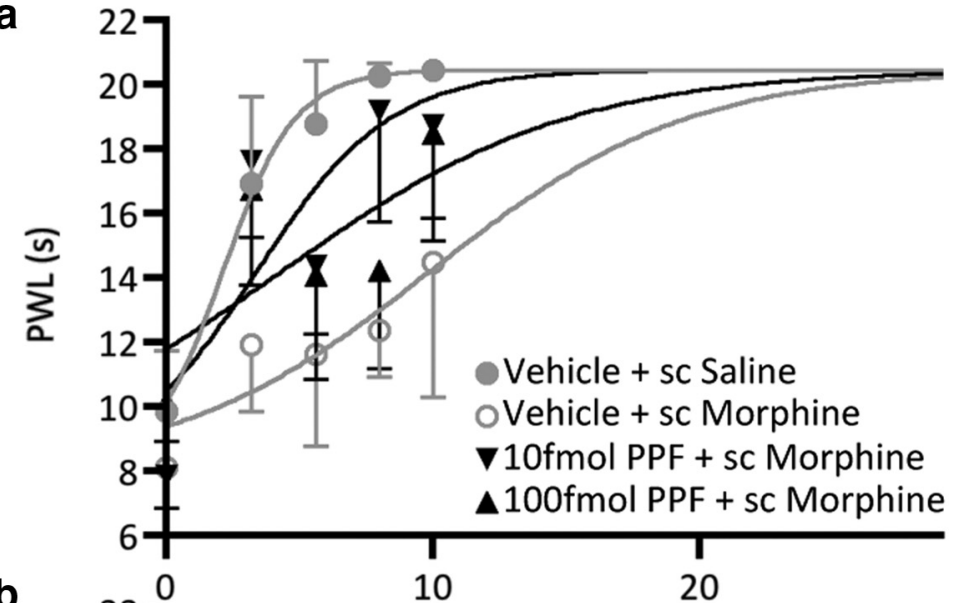

b

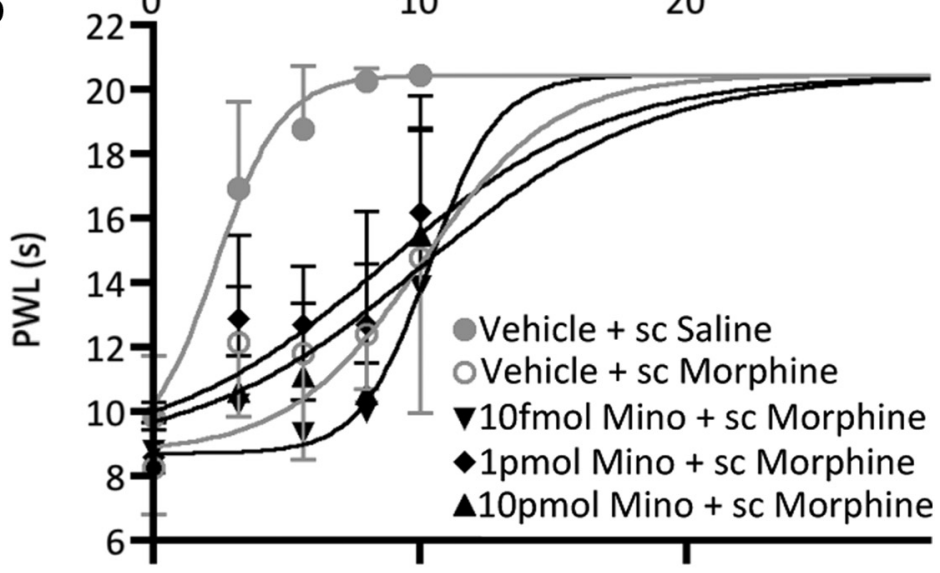

C

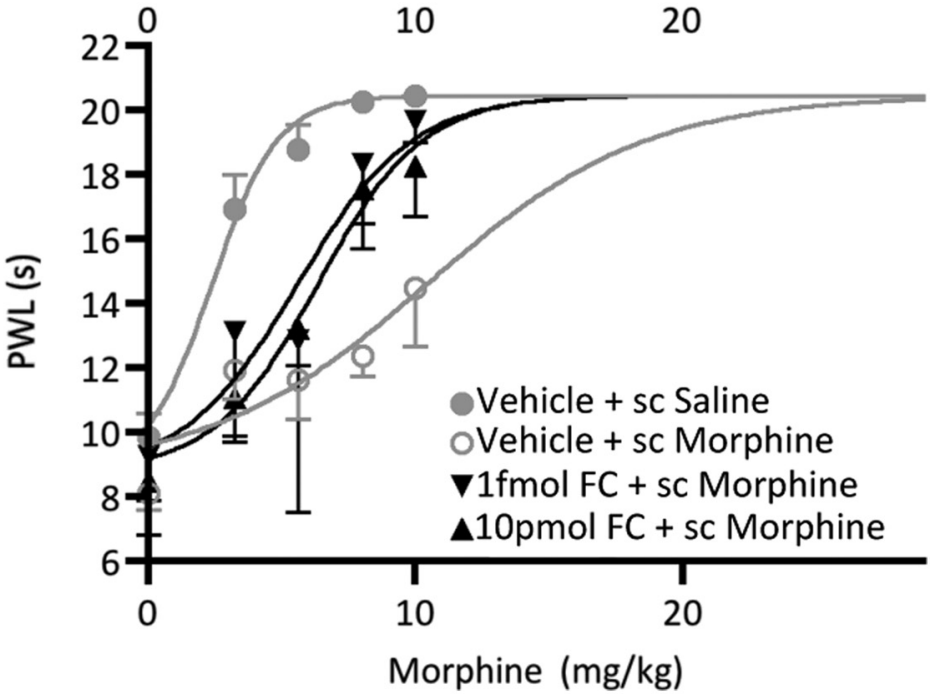

Figure 1. PWL represented as mean $D_{50} \pm 95 \% \mathrm{Cl}$ as a function of cumulative injections of morphine in rats treated with $(\boldsymbol{a})$ vIPAG vehicle + scSaline $(n=6)$, vIPAG vehicle + scMorphine $(n=9)$, and vIPAG propentofylline $(10 \mathrm{fmol}, n=5 ; 100 \mathrm{fmol}, n=$ 9) and sc Morphine, $(\boldsymbol{b})$ vIPAG vehicle $+s c$ Saline $(n=6)$, vIPAG vehicle $+s c$ Morphine $(n=8)$, and vIPAG minocycline (10 fmol, $n=9 ; 1 \mathrm{pmol}, n=12 ;$ or $10 \mathrm{pmol}, n=4)$ and sc Morphine, and (c) vIPAG vehicle + sc Saline $(n=6)$, vlPAG vehicle $+\mathrm{sc}$ Morphine $(n=9)$, and vIPAG fluorocitrate ( $1 \mathrm{fmol}, n=5 ; 10 \mathrm{pmol}, n=6)$ and sc Morphine.

was chosen based on vlPAG doses of $(-)$-morphine, and the fact that $(+)$ - and (-)-morphine activate the TLR4 signaling cascade to a similar degree in vitro (Lane et al., 2005; Hutchinson et al., 2010b). Twenty-four hours following intra-vlPAG injections of TLR4 agonists, animals were given cumulative challenge doses of subcutaneous morphine and PWLs were tested to assess tolerance development as described above. Data analysis and presentation are as described above.
Experiment 3: influence of TLR4 on acute morphine antihyperalgesia

Morphine is primarily consumed for the alleviation of severe pain, and chronic morphine use is associated with tolerance development. Therefore, our final series of experiments were conducted to determine whether blockade of vlPAG TLR4 with (+)-naloxone would potentiate the antihyperalgesic effect of morphine in a model of persistent inflammatory pain.

In a separate group of animals, persistent inflammatory hyperalgesia was induced by injection of complete Freund's adjuvant (CFA; 200 $\mu \mathrm{l}$; Sigma), suspended in an oil/saline (1:1) emulsion, into the plantar surface of the right hindpaw as previously described (Loyd and Murphy, 2006; Wang et al., 2006; Loyd et al., 2008a). Twenty-four hours following intraplantar CFA injection, acute antihyperalgesia was measured by injecting cumulative doses of morphine every $20 \mathrm{~min}$, resulting in doses of $3.2,5.6,8.0,10.0$, and $18.0 \mathrm{mg} / \mathrm{kg}$ subcutaneously (NIDA). Hyperalgesia was assessed using the paw thermal stimulator at baseline, and 15 min after each injection, as described above (Hargreaves et al., 1988; Wang et al., 2006). Animals received one subcutaneous injection of (+)-naloxone $(8 \mathrm{mg} / \mathrm{kg}$, s.c.; NIDA) or saline $(1 \mathrm{ml} / \mathrm{kg}$, s.c.) with the first dose of morphine to produce two treatment groups $[(+)$ Naloxone/Morphine; Vehicle/Morphine]. A separate group of animals received repeated injections of saline on the same time course as the cumulative morphine doses to determine whether $(+)$-naloxone induces antihyperalgesia in the absence of morphine $[(+)$-Naloxone/Vehicle]. The $8 \mathrm{mg} / \mathrm{kg}$ dose of (+)-naloxone was chosen based on previous studies demonstrating it to be sufficient to potentiate acute morphine analgesia in the absence of pain (Hutchinson et al., 2010b). Animals were acclimated to the testing apparatus (30 min a day for 3 consecutive days) at the start of the experiment. All behavioral testing took place between 12:00 and 5:00 P.M. (lights on at 7:00 A.M.). All testing was conducted blind with respect to group assignment. Data analysis and presentation are as described above.

\section{Results}

Experiment 1: inhibition of vlPAG microglia and astrocyte activity attenuated morphine tolerance $v l P A G$ infusions of propentofyllineattenuated morphine tolerance

Administration of cumulative doses of morphine produced an increase in PWL in all animals tested (Fig. 1a). ANOVA revealed a significant main effect of treatment $\left(F_{(4,27)}=7.84 ; p=0.0002\right)$, with the antinociceptive potency of morphine being greatest in rats pretreated with vlPAG Vehicle + sc Saline for $3 \mathrm{~d}\left(\mathrm{D}_{50}=2.499 \mathrm{mg} / \mathrm{kg}, \mathrm{CI}=1.917-3.081\right)$. In contrast, pretreatment with vlPAG Saline + sc Morphine resulted in a significant fourfold rightward shift in the dose-response curve $\left(D_{50}=10.64\right.$ $\mathrm{mg} / \mathrm{kg}, \mathrm{CI}=7.636-13.65 ; p=0.0004)$, indicating tolerance to morphine. Intra-vlPAG pretreatment with $100 \mathrm{fmol}$ of propento- 
fylline significantly increased the antinociceptive potency of morphine $\left(\mathrm{D}_{50}=5.48 \mathrm{mg} / \mathrm{kg}, \mathrm{CI}=3.503-7.464\right)$ compared with animals made tolerant to morphine (vlPAG Vehicle + sc Morphine; $p=0.0054$ ). However, the $\mathrm{D}_{50}$ for these animals was significantly increased compared with saline controls (vlPAG Vehicle + sc Saline; $p=0.030$ ), indicating an attenuation, but not elimination, of tolerance. Propentofylline (10 fmol) significantly increased the antinociceptive potency of morphine $\left(\mathrm{D}_{50}=4.02\right.$ $\mathrm{mg} / \mathrm{kg}, \mathrm{CI}=2.203-5.787)$ compared with animals made tolerant to morphine (Vehicle + sc Morphine; $p=0.0046$ ). Indeed, animals treated with $10 \mathrm{fmol}$ propentofylline did not differ from saline controls (vlPAG Vehicle + sc Saline; $p=0.054$ ) indicating a complete abolishment of tolerance. Animals pretreated with 10 fmol propentofylline in the absence of morphine (vlPAG PPF + sc Saline; $\mathrm{D}_{50}$ $=4.318 \mathrm{mg} / \mathrm{kg}, \mathrm{CI}=1.730-6.905, n=3$ ) did not differ from vehicle controls (vlPAG Vehicle + sc Saline; $p=0.0796$; data not shown) indicating that chronic pretreatment with propentofylline alone does not potentiate morphine analgesia. Additionally, these effects were site specific as animals treated with $10 \mathrm{fmol}$ propentofylline outside of the PAG (cannulae misses; $n=5$ ) and subcutaneous morphine $\left(\mathrm{D}_{50}=11.53, \mathrm{CI}=6.633-16.43\right)$ significantly differed from animals treated with vlPAG Vehicle + sc Saline $(p=0.0012)$, and did not differ from vlPAG Vehicle + sc Morphine-treated animals ( $p=0.735$, data not shown). Together, these results indicate that propentofylline is sufficient to attenuate the development of tolerance to subcutaneous morphine, and suggest that glial cell activity in the vlPAG contributes to the development of morphine tolerance.

Inhibition of vlPAG microglia activity with minocycline was not sufficient to attenuate morphine tolerance

Morphine tolerance, assessed using a cumulative dosing paradigm, was observed in all groups that received subcutaneous morphine once a day for $3 \mathrm{~d}$ (Fig. $1 b$ ). ANOVA of the data indicated a significant main effect of treatment $\left(F_{(4,34)}=8.82 ; p<\right.$ $0.0001)$. Post hoc analysis revealed that the antinociceptive potency of morphine was significantly decreased in animals that received $3 \mathrm{~d}$ of vlPAG Vehicle + sc Morphine $\left(\mathrm{D}_{50}=10.13\right.$ $\mathrm{mg} / \mathrm{kg}, \mathrm{CI}=6.991-13.27)$ compared with animals that received $3 \mathrm{~d}$ of vlPAG Vehicle $+\mathrm{sc}$ Saline $\left(\mathrm{D}_{50}=2.37 \mathrm{mg} / \mathrm{kg}, \mathrm{CI}=1.793-\right.$ $2.938)$, indicating tolerance to morphine $(p=0.0006)$. Animals that received intra-PAG injections of the microglial cell activity inhibitor minocycline had $\mathrm{D}_{50}$ values that did not differ from animals made tolerant to morphine ( $10 \mathrm{fmol}: \mathrm{D}_{50}=10.35 \mathrm{mg} / \mathrm{kg}$, $\mathrm{CI}=9.185-11.51, p=0.445 ; 1$ pmol: $\mathrm{D}_{50}=8.67 \mathrm{mg} / \mathrm{kg}, \mathrm{CI}=$ 6.882-10.46, $p=0.196 ; 10$ pmol: $D_{50}=10.03 \mathrm{mg} / \mathrm{kg}, \mathrm{CI}=$ $8.031-12.02, p=0.483$ ). Additionally, all animals treated with minocycline had $D_{50}$ values that were significantly greater than animals treated with vlPAG Vehicle + sc Saline $(10$ fmol: $p<$ 0.0001; 1 pmol: $p<0.0001$; 10 pmol: $p<0.0001)$ indicating tolerance to morphine. These results indicate that blockade of vlPAG microglial cell activity is not sufficient to attenuate the development of morphine tolerance.

\section{Inhibition of vlPAG astrocyte activation with fluorocitrate} attenuated morphine tolerance

Administration of cumulative doses of morphine produced an increase in PWL in all animals tested (Fig. 1c). ANOVA indicated a significant main effect of treatment $\left(F_{(3,22)}=10.50 ; p=\right.$ $0.0002)$. Morphine antinociception was significantly decreased in animals that received vlPAG Vehicle + sc Morphine $\left(D_{50}=10.44\right.$ $\mathrm{mg} / \mathrm{kg}, \mathrm{CI}=7.488-13.39)$ compared with animals that received vlPAG Vehicle + sc Saline $\left(\mathrm{D}_{50}=2.39 \mathrm{mg} / \mathrm{kg}, \mathrm{CI}=1.817-\right.$ $2.966)$, indicating tolerance to morphine $(p=0.0004)$. The as- trocyte activity inhibitor fluorocitrate (1 fmol and $10 \mathrm{pmol})$ attenuated tolerance to morphine compared with animals treated with vlPAG Vehicle + sc Morphine $\left(1 \mathrm{fmol}: \mathrm{D}_{50}=5.61 \mathrm{mg} / \mathrm{kg}\right.$, $\mathrm{CI}=4.406-6.819, p=0.018 ; 10$ pmol: $\mathrm{D}_{50}=6.36 \mathrm{mg} / \mathrm{kg}, \mathrm{CI}=$ $5.337-7.381, p=0.023)$. However, animals treated with fluorocitrate showed a significant rightward shift in the dose-response curve compared with animals treated with vlPAG Vehicle $+\mathrm{sc}$ Saline ( 1 fmol: $p=0.0003 ; 10$ pmol: $p<0.0001$ ). These results indicate that fluorocitrate is sufficient to attenuate, but not eliminate, the development of morphine tolerance, and suggests that vlPAG astrocyte activity contributes to the development of morphine tolerance.

\section{Experiment 1.2: anatomical assessment of vlPAG glial cell inhibition}

To assess the efficacy of the metabolic glial inhibitors administered, immunohistochemistry, in combination with densitometry, was used to measure microglia and astrocyte activity within the PAG. In agreement with our previous findings, subcutaneous injections of morphine once daily for $3 \mathrm{~d}$ significantly increased vlPAG microglia activity as evidenced by an increase in OX-42 immunoreactivity (Fig. 2a) compared with saline controls $\left(F_{(8,19)}=6.54 ; p=0.002\right.$; Eidson and Murphy, 2013). vlPAG microinfusions of the microglial cell metabolic inhibitor minocycline at $10 \mathrm{fmol}, 1 \mathrm{pmol}$, and $10 \mathrm{pmol}$ concentrations significantly decreased microglia $(p=0.0008,0.0002$, and $p<0.0001$, respectively; Fig. $2 a$ ), but not astrocyte activity $(p=0.15,0.36$, and 0.25 , respectively; data not shown), compared with animals treated with vlPAG Vehicle + sc Morphine. The effect was dose dependent with the highest concentration of minocycline being most effective at decreasing morphine-induced microglial cell activation. These results confirm that minocycline specifically inhibited microglia, and not astrocytes, and suggest that minocycline's inability to attenuate morphine tolerance was not due to insufficient microglia inhibition by our drug infusions.

Similar to what was noted for microglia, and in agreement with our previous findings, chronic subcutaneous morphine significantly increased vlPAG astrocyte activity, as evidenced by an increase in GFAP immunoreactivity (Fig. 2b) compared with saline controls $\left(F_{(8,17)}=7.14 ; p=0.038\right.$; Eidson and Murphy, 2013). vlPAG microinfusions of the astrocyte metabolic inhibitor fluorocitrate ( $1 \mathrm{fmol}$ and $10 \mathrm{pmol}$ ) dose dependently decreased astrocyte ( $p=0.059$ and 0.0001 , respectively; Fig. $2 b$ ) but not microglia activity ( $p=0.11$ and 0.56 , respectively; data not shown) in the vlPAG compared with animals treated with vlPAG Vehicle + sc Morphine. This effect was dose dependent such that only the 10 pmol dose significantly decreased morphine-induced astrocyte activation. These results confirm that fluorocitrate was specifically targeting astrocytes, and not microglia.

Finally, vlPAG microinfusions of the general glial cell metabolic inhibitor propentofylline (10 and $100 \mathrm{fmol}$ ) significantly decreased morphine-induced activation of microglia and astrocytes, as evidence by reduced vlPAG expression of OX-42 (Fig. $2 a$; $p=0.002$ and 0.0002, respectively) and GFAP (Fig. $2 b ; p=$ 0.0003 and 0.0005 , respectively) compared with animals treated with vlPAG Vehicle + sc Morphine. These results indicate that administration of propentofylline inhibits morphine-induced activation of both microglia and astrocytes, and together with our behavioral data, indicate that concurrent blockade of both microglia and astrocytes was sufficient to attenuate the development of tolerance to morphine. 

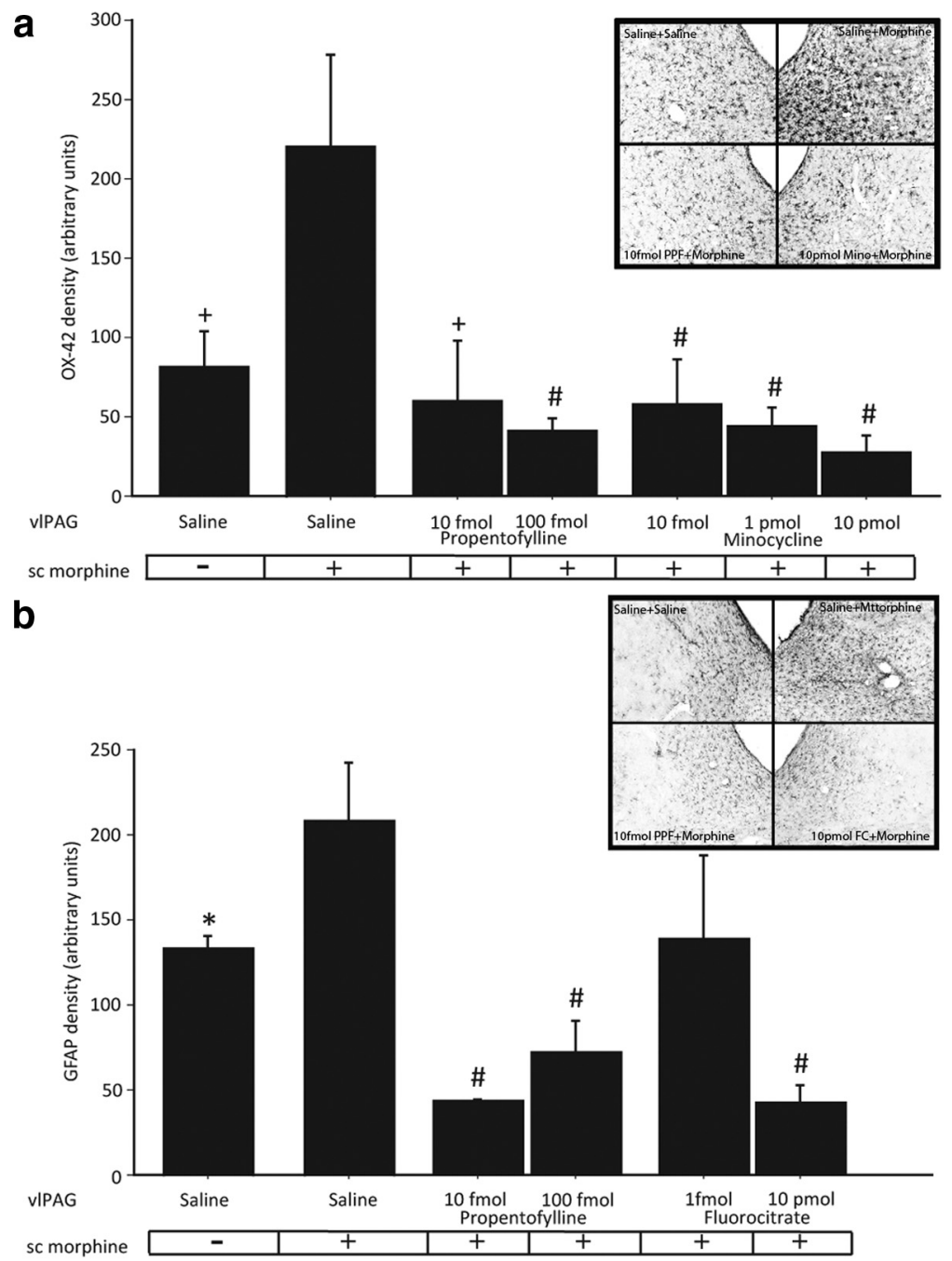

Figure 2. Densitometry of OX-42 (a) and GFAP $(\boldsymbol{b})$ immunoreactivity in the vIPAG Saline $+s c$ Saline $(n=6)$, vIPAG Saline + scMorphine $(n=8)$, vlPAG propentofylline (PPF; $10 \mathrm{fmol}, n=5$ and $100 \mathrm{fmol}, n=9)+\mathrm{sc}$ Morphine, vlPAG minocycline (10 fmol, $n=9 ; 1 \mathrm{pmol}, n=12$; and $10 \mathrm{pmol}, n=4)+\mathrm{sc}$ Morphine, and vIPAG fluorocitrate $(1 \mathrm{fmol}, n=5$ and $10 \mathrm{pmol}, n=6)+\mathrm{sc}$ Morphine groups. ${ }^{*} p<0.05,+p<0.01$, and \#p $<0.001$ indicate that groups are significantly different from the vIPAG Saline + sc Morphine group. Insets are representative photomicrographs (10X) of 0X-42 (a) and GFAP (b) immunoreactivity in the vIPAG (bregma -7.08) of animals treated with vIPAG Saline + sc Saline, vIPAG Saline + sc Morphine, vIPAG $10 \mathrm{fmol}$ PPF + sc Morphine, and vIPAG 10 pmol Mino + sc Morphine (from left to right; $\boldsymbol{a}$ ) and vIPAG Saline + sc Saline, vIPAG Saline + sc Morphine, vIPAG 10 fmol PPF + sc Morphine, and vIPAG 10 pmol FC + sc Morphine (from left to right; $\boldsymbol{b}$ ).

Experiment 2: vlPAG TLR4 was both necessary and sufficient for the development of morphine tolerance

Results from Experiment 1 indicate that both microglia and astrocyte activity within the vlPAG increase in response to chronic morphine administration, and that blockade of microglia and astrocyte, or just astrocyte activation, attenuates the development of morphine tolerance. To investigate the mechanism by which morphine affects glia and contributes to tolerance, we characterized MD-2 expression in the dlPAG and vlPAG, and tested the hypothesis that morphine-induced activation of TLR4 within the vlPAG mediates morphine tolerance development.

\section{Experiment 2.1: dlPAG and vlPAG localization of MD-2}

In these studies, immunohistochemistry was used to characterize MD-2 expression within the vlPAG. The dlPAG, a region not implicated in morphine tolerance development (Tortorici et al., 1999), was also examined. As indicated in the photomicrograph (Fig. $3 a$, inset), MD-2 is present and densely expressed within the
vlPAG. This region of the PAG contains a high density of MORs (Mansour et al., 1986, 1987; Kalyuzhny et al., 1996; Commons et al., 1999, 2000; Wang and Wessendorf, 2002; Loyd et al., 2008b). A comparison of vlPAG (bregma -6.72 through -8.76) and dlPAG (bregma -6.72 through -8.04 ; Fig. $3 a$ ) revealed significantly greater MD-2 immunoreactivity in the vlPAG compared with the dl$\operatorname{PAG}\left(F_{(4,1)}=11.275 ; p=0.0284\right)$. MD-2 expression was homogeneous across levels of the vlPAG $\left(F_{(3,5)}=2.702 ; p=0.062\right)$ and $\operatorname{dlPAG}\left(F_{(4,3)}=1.413 ; p=0.2872\right.$; Fig. $3 b$ ). Post hoc analysis revealed significantly greater MD-2 immunoreactivity in the vlPAG compared with the dIPAG at both rostral (bregma $-6.72 ; p=0.0458$ ) and caudal (bregma $-8.04 ; p=0.0380$ ) levels (Fig. 3b).

\section{Experiment 2.2: antagonism of vlPAG TLR4 with LPS-RS or (+)-naloxone attenuated the development of morphine tolerance}

ANOVA of the data indicated a significant main effect of treatment $\left(F_{(3,22)}=5.35 ; p=\right.$ 0.0064; Fig. 4a). The antinociceptive potency of morphine was significantly decreased in animals that received $3 \mathrm{~d}$ of morphine ( $5 \mathrm{mg} / \mathrm{kg}$; s.c.) and intra-vlPAG saline $\left(D_{50}=10.86 \mathrm{mg} / \mathrm{kg}, \mathrm{CI}=7.463\right.$ 14.26) compared with animals that received $3 \mathrm{~d}$ of saline $(1 \mathrm{ml} / \mathrm{kg})$ and intra-vlPAG vehicle $\left(D_{50}=6.03 \mathrm{mg} / \mathrm{kg}, \mathrm{CI}=5.216-6.835\right.$; $p=0.0051)$, indicating tolerance to morphine (Fig. 4a). vlPAG microinjections of the TLR4 antagonist LPS-RS dose dependently eliminated the development of morphine tolerance. The antinociceptive potency of morphine was significantly increased in animals treated with $2.4 \mu \mathrm{g}$ of LPS-RS $\left(\mathrm{D}_{50}=4.501 \mathrm{mg} / \mathrm{kg}, \mathrm{CI}=3.398-\right.$ 5.605) compared with animals made tolerant to morphine $(p=0.0031)$ indicating blockade of tolerance. These results were limited to the vlPAG as the $\mathrm{D}_{50}$ for animals treated with $2.4 \mu \mathrm{g}$ LPS-RS into misplaced cannulae (cannulae misses, $\mathrm{D}_{50}=8.237, \mathrm{CI}=7.320-11.15$ ) did not differ from vehicle controls (vlPAG Vehicle $+\mathrm{sc}$ Morphine, $p=0.4555$; data not shown). No significant difference in $\mathrm{D}_{50}$ was noted in animals treated with $1.7 \mu$ g of LPS-RS $\left(D_{50}=11.54 \mathrm{mg} / \mathrm{kg}, \mathrm{CI}=5.447-\right.$ 17.62) compared with the vlPAG Vehicle + sc Morphine group $(p=0.4168)$. These results indicate that vlPAG TLR4 is necessary for the development of morphine tolerance.

The MOR is stereoselective such that only the (-)stereoisomers of opioids bind. Conversely, opioid agonists and antagonists (e.g., naloxone) affect TLR4 in a nonstereoselective fashion, with both $(-)$ - and $(+)$-stereoisomers affecting the signaling cascade in a manner that maintains their agonistic and antagonistic properties (Hutchinson et al., 2008b, 2010b).

The antinociceptive potency of morphine was significantly decreased $\left(F_{(3,21)}=8.968 ; p=0.0005\right.$; Fig. $\left.4 b\right)$ in animals that received $3 \mathrm{~d}$ of morphine $(5 \mathrm{mg} / \mathrm{kg}$, s.c.) and intra-vlPAG saline 
$\left(D_{50}=10.75 \mathrm{mg} / \mathrm{kg}, \mathrm{CI}=7.274-14.23\right)$ compared with animals that received $3 \mathrm{~d}$ of saline $(1 \mathrm{ml} / \mathrm{kg}$, s.c.) and intra-vlPAG vehicle $\left(\mathrm{D}_{50}=5.801 \mathrm{mg} / \mathrm{kg}, \mathrm{CI}=5.002-\right.$ $6.600 ; p=0.0050)$ indicating tolerance to morphine (1.8-fold rightward shift in the dose-response curve). Similar to what was observed for LPS-RS, antagonism of TLR4 with $(+)$-naloxone $(5 \mu \mathrm{g} / 0.5 \mu \mathrm{l})$ abolished the development of morphine tolerance. The antinociceptive potency of morphine was significantly increased in animals treated with $(+)$-naloxone $\left(\mathrm{D}_{50}=3.529 \mathrm{mg} / \mathrm{kg}, \mathrm{CI}=2.344-4.715\right)$, compared with animals treated with vlPAG Vehicle + sc Morphine $(p=0.0101$; Fig. $4 b) .(+)$-Naloxone also resulted in a significant leftward shift in the dose-response curve compared with the vlPAG Vehicle + sc Saline group $(p=0.0056)$. However, $(+)$-naloxone pretreatment in the absence of morphine was without effect. Indeed, the $D_{50}$ for the vlPAG $(+)$ naloxone + sc Saline group $\left(D_{50}=6.315\right.$ $\mathrm{mg} / \mathrm{kg}, \mathrm{CI}=5.440-6.830)$ did not differ from the vlPAG Vehicle + sc Saline group $(p=0.5979)$, indicating that vlPAG TLR4 inhibition does not affect antinociception in the absence of morphine, and suggesting that TLR4 is not constitutively activated. These results further support our hypothesis that vlPAG TLR4 is necessary for the development of morphine tolerance.

\section{Experiment 2.3: activation of vlPAG TLR4 with LPS, KDO2, or (+)-morphine-induced naive tolerance}

Intra-vlPAG microinjections of the TLR4 agonist LPS dose dependently induced tolerance to morphine $\left(F_{(3,24)}=6.190 ; p=\right.$ 0.0029; Fig. $5 a)$. Indeed, rats pretreated with vlPAG LPS $(5 \mu \mathrm{g})$ alone $\left(D_{50}=9.113 \mathrm{mg} / \mathrm{kg}, \mathrm{CI}=8.052-10.170\right)$ did not differ from rats given morphine once a day for $3 \mathrm{~d}\left(\mathrm{D}_{50}=10.81 \mathrm{mg} / \mathrm{kg}\right.$, $\mathrm{CI}=7.354-14.260 ; p=0.1958)$, indicating naive tolerance to morphine. Additionally, rats pretreated with vlPAG LPS $(5 \mu \mathrm{g})$ or rats treated with vlPAG Vehicle + sc Morphine showed significant decreases in the antinociceptive potency of morphine $(p=$ 0.0001 and $p=0.0050$, respectively) compared with rats treated with vlPAG Vehicle $\left(D_{50}=5.896 \mathrm{mg} / \mathrm{kg}, \mathrm{CI}=5.093-6.700\right)$. The lowest dose of LPS $\left(1.7 \mu \mathrm{g} ; \mathrm{D}_{50}=6.462 \mathrm{mg} / \mathrm{kg}, \mathrm{CI}=5.439-\right.$ 7.485 ) was without effect (i.e., these animals did not show signs of tolerance compared with vehicle controls $(p=0.1936))$. These results indicate that vlPAG TLR4 agonism is sufficient to induce the development of morphine tolerance.

Similar to what was noted for LPS, intra-vlPAG microinjections of the TLR4 agonist KDO2 dose dependently reduced the antinociceptive potency of morphine $\left(F_{(4,26)}=4.659 ; p=0.0057\right.$; Fig. $5 b$ ) with the $5 \mu \mathrm{g}$ dose having the most robust effect. The antinociceptive potency of morphine did not differ in animals pretreated with $5 \mu \mathrm{g}$ of $\mathrm{KDO} 2\left(\mathrm{D}_{50}=7.922 \mathrm{mg} / \mathrm{kg}, \mathrm{CI}=6.391-\right.$ 9.453) compared with morphine-pretreated animals $\left(\mathrm{D}_{50}=\right.$ $10.84 \mathrm{mg} / \mathrm{kg}, \mathrm{CI}=7.415-14.260 ; p=0.0816)$ indicating the development of naive tolerance. Indeed, both KDO2 $(5 \mu \mathrm{g})$ and morphine pretreatment caused a significant rightward shift in the
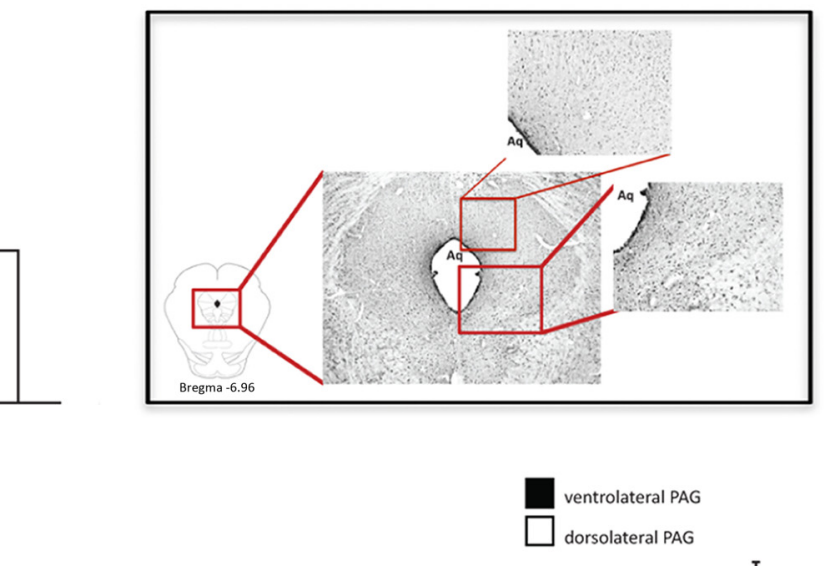

dorsolateral PAG

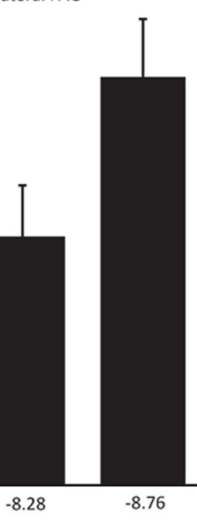

Bregma level

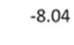

Figure 3. MD-2 immunoreactivity in the vIPAG and dIPAG of normal adult male rats $(n=5)$ collapsed across bregma levels $(\boldsymbol{a})$ (Paxinos and Watson, 1977). Representative photomicrographs of dIPAG and vIPAG MD-2 immunoreactivity shown at $4 \times$ (middle) and $10 \times$ (right) magnifications ( $\boldsymbol{a}$, inset). Aq denotes the location of the cerebral aqueduct.

morphine dose-response curve $(p=0.0044$ and $p=0.0015$, respectively) compared with saline controls $\left(D_{50}=5.720 \mathrm{mg} / \mathrm{kg}\right.$, $\mathrm{CI}=5.024-6.416)$.

Intra-vlPAG administration of the TLR4 stereoselective agonist $(+)$-morphine also induced naive morphine tolerance $\left(F_{(2,21)}=5.949 ; p=0.0090\right.$; Fig. $\left.5 \mathrm{c}\right)$. Indeed, the $\mathrm{D}_{50}$ for animals pretreated with $5 \mu \mathrm{g}$ of $(+)$-morphine $\left(\mathrm{D}_{50}=8.218 \mathrm{mg} / \mathrm{kg}, \mathrm{CI}=\right.$ 7.144-9.293) did not differ from animals that received $3 \mathrm{~d}$ of (-)-morphine (s.c.) $\left(\mathrm{D}_{50}=10.86 \mathrm{mg} / \mathrm{kg}, \mathrm{CI}=7.461-14.26 ; p=\right.$ $0.0513)$. Additionally, both $(-)$ - and $(+)$-morphine groups had a significant increase in $\mathrm{D}_{50}(p=0.0072$ and $p=0.0037$, respectively) compared with saline controls $\left(D_{50}=5.921 \mathrm{mg} / \mathrm{kg}, \mathrm{CI}=\right.$ 5.014-6.828). Together, these results are the first to indicate that morphine activation of vlPAG glia contributes to the development of morphine tolerance, and that vlPAG TLR4 is both necessary and sufficient for the development of morphine tolerance.

Experiment 3: acute systemic antagonism of TLR4 potentiated acute morphine antihyperalgesia in a model of persistent inflammatory pain

The results from the studies above indicate that antagonism of TLR4 attenuates the development of tolerance to morphine, providing additional evidence that glia actively oppose the antinociceptive actions of morphine. Therefore, in our final series of experiments we tested the hypotheses that blockade of TLR4 potentiates the analgesic effects of acute morphine. As morphine is primarily consumed for the alleviation of severe pain, these studies were conducted in animals experiencing persistent inflamma- 

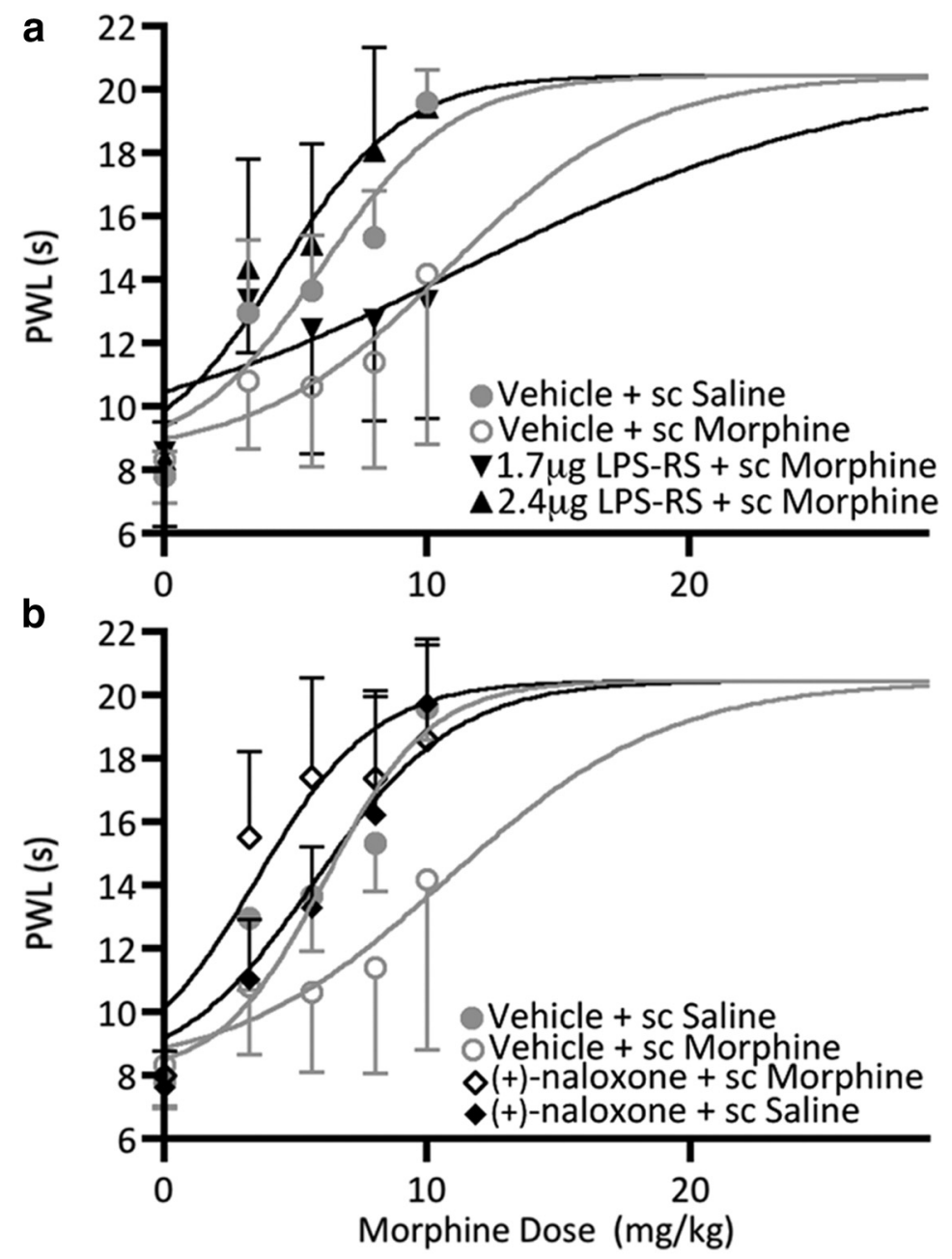

Figure 4. PWL represented as mean $\mathrm{D}_{50} \pm 95 \% \mathrm{Cl}$ as a function of cumulative injections of morphine in rats treated with (a) vIPAG Vehicle $+s c$ Saline $(n=8)$, vIPAG Vehicle + sc Morphine $(n=7)$, and vIPAG LPS-RS $(1.7 \mu \mathrm{g}, n=5 ; 2.4 \mu \mathrm{g}$, $n=6)+$ sc Morphine, and $(\boldsymbol{b})$ vIPAG Vehicle + sc Saline $(n=8)$, vIPAG Vehicle + sc Morphine $(n=7)$, and vIPAG (+)-naloxone $(5 \mu \mathrm{g} / 0.5 \mu \mathrm{l})+$ sc Morphine $(n=6)$, and vIPAG $(+)$-naloxone + sc Vehicle $(n=4)$.

tory hyperalgesia. Systemic antagonism of TLR4 with $(+)$ naloxone $(8 \mathrm{mg} / \mathrm{kg})$ significantly potentiated acute morphine antihyperalgesia compared with subcutaneous vehicle/subcutaneous morphine-treated animals $\left(t_{(11)}=3.811 ; p=0.0014\right.$; Fig. 6). Indeed, the potency of morphine was significantly increased in animals treated with $(+)$-naloxone $\left(D_{50}=3.415 \mathrm{mg} / \mathrm{kg}, \mathrm{CI}=3.093-\right.$ $3.737)$ compared with vehicle controls $\left(D_{50}=5.609 \mathrm{mg} / \mathrm{kg}, \mathrm{CI}=\right.$ 4.727-6.490). Consistent with previous results, $(+)$-naloxone, in the absence of morphine, exhibited acute antihyperalgesic effects resulting in a slight increase in PWL across the testing period (Lewis et al., 2012). These results, together with our previous studies, indicate that TLR4 opposes both the acute and chronic effects of morphine.

\section{Discussion}

The present set of experiments tested the hypothesis that vlPAG glia contribute to the development of morphine tolerance through the innate immune receptor TLR4. Here we report that (1) vlPAG microinjections of the general glial metabolic inhibitor propentofylline or the astrocyte inhibitor fluorocitrate significantly decreased morphine-induced glia activation in the vlPAG, and attenuated the development of tolerance to systemically administered morphine; (2) vlPAG TLR4 antagonism prevented the development of tolerance to systemic morphine; and (3) vlPAG TLR4 agonism induced a naive tolerance to subsequent challenge doses of morphine. Based on these findings we hypothesized that blockade of TLR4 would potentiate the antinociceptive effects of morphine in a model of persistent inflammatory pain. Indeed, systemic antagonism of TLR4 significantly enhanced the acute antihyperalgesic effects of systemic morphine. Together, these data demonstrate a role for vlPAG glia in the development of morphine tolerance, and establish the vlPAG as a CNS locus through which TLR4 mediates morphine tolerance development. The results of our acute studies implicate TLR4 as a potential therapeutic target for the treatment of pain.

\section{vlPAG glia contribute to morphine tolerance}

It is now well established that opioids, including morphine, activate spinal glia to produce a potent proinflammatory response that opposes both acute and chronic morphine analgesia (Hutchinson et al., 2007). Morphine administration increases the expression of microglia and astrocyte activity markers OX-42 and GFAP and induces the release of glially derived proinflammatory cytokines (Song and Zhao, 2001; Raghavendra et al., 2002). In agreement with our previous findings, here we show that in the absence of pain, tolerance to morphine developed rapidly (Loyd et al., 2008a; Eidson and Murphy, 2013). Indeed, administration of one $\mathrm{ED}_{50}$ dose of morphine $(5 \mathrm{mg} / \mathrm{kg}$ ) for $3 \mathrm{~d}$ was sufficient to induce behaviorally defined tolerance. Paralleling the development of tolerance, OX-42 and GFAP protein levels increased significantly within the vlPAG, suggesting the activation of microglia and astrocytes, respectively (Eidson and Murphy, 2013). These results demonstrate that the vlPAG proinflammatory response contributes to the development of morphine tolerance. Indeed, intra-PAG administration of propentofylline, which inhibits both microglia and astrocyte activity by reducing proinflammatory cytokine release, dose dependently decreased vlPAG microglia and astrocyte activity, and attenuated tolerance to morphine (Sweitzer et al., 2001; Raghavendra et al., 2003). Decreased astrocyte activity appears to drive this effect in part, as inhibition of astrocytes alone with fluorocitrate led to an attenuation of tolerance. Proinflammatory cytokines, particularly tumor necrosis factor $\alpha(\mathrm{TNF} \alpha)$, increase the density and conductance of neuronal GluR2-lacking AMPA receptors (AMPARs; via neuronal PI3K and TNFR1 but not TNFR2), and decrease $\mathrm{GABA}_{\mathrm{A}}$ receptors via endocytosis. These changes increase miniature EPSCs and decrease miniature IPSCs in hippocampal slices and cultured hippocampal neurons (Stellwagen et al., 2005). The proinflammatory cytokine IL- $1 \beta$ significantly increases neuronal GluR2-lacking AMPARs, albeit to a lesser extent (Ogoshi et al., 2005; Stellwagen et al., 2005). TNF $\alpha$ also decreases astrocytic 
glutamate transporter proteins (GLT-1, GLAST) in the spinal cord presumably leaving more glutamate available in the synapse (Hameed et al., 2010). Together, these cytokine-induced changes, among others, effectively increase neuronal excitability (Morioka et al., 2002; Kleibeuker et al., 2007). This increased excitation may contribute to morphine tolerance by actively opposing the inhibitory properties of morphine.

Our findings within the PAG complement a vast literature indicating that spinal cord glia contribute to morphine tolerance development, and indicate a role for supraspinal glial cell activity as well (Song and Zhao, 2001; Johnston et al., 2004; Mika, 2008; Hutchinson et al., 2008a). Consistent with our results, intrathecal administration of propentofylline increases acute opioid analgesia and attenuates morphine tolerance (Raghavendra et al., 2003, 2004). However, in contrast to the spinal cord, where either inhibition of microglia or astrocytes alone is sufficient to attenuate the development of morphine tolerance, here inhibition of astrocytes alone was effective in attenuating tolerance (Song and Zhao, 2001; Cui et al., 2008). While microglia are classically viewed as initiators of neuroinflammation, chronic morphine can cause neurons to release factors that activate both microglia and astrocytes (e.g., fractalkine, dynorphin, and nitric oxide), and astrocytes can express TLR4 (Nichols et al., 1997; Lehnardt et al., 2003; Johnston et al., 2004; Watkins et al., 2005). Therefore, it is conceivable that while morphine activates both microglia and astrocytes, blocking astrocyte activation alone reduces opiate-induced changes in neuronal excitability that contribute to morphine tolerance development and maintenance.

\section{vlPAG TLR4 modulates morphine tolerance development}

There is extensive literature supporting a critical role for glial cell activation in the development of morphine tolerance. Until relatively recently, however, the mechanism by which opioids induce the activation of glia was unknown. Demonstration that opioid hyperalgesia is still observed in neuronal opioid receptor $(\mu, \delta$, and $\kappa)$ knock-out mice led to the consideration that the anti-analgesic effects of morphine (e.g., tolerance) may be mediated by non-neuronal opioid receptors (Juni et al., 2007). Interestingly, glial activation induced by other stimuli such as neuropathic pain or LPS administration, also reduces the analgesic efficacy of intrathecal morphine, an effect attenuated by intrathecal administration of the neuronal opi-

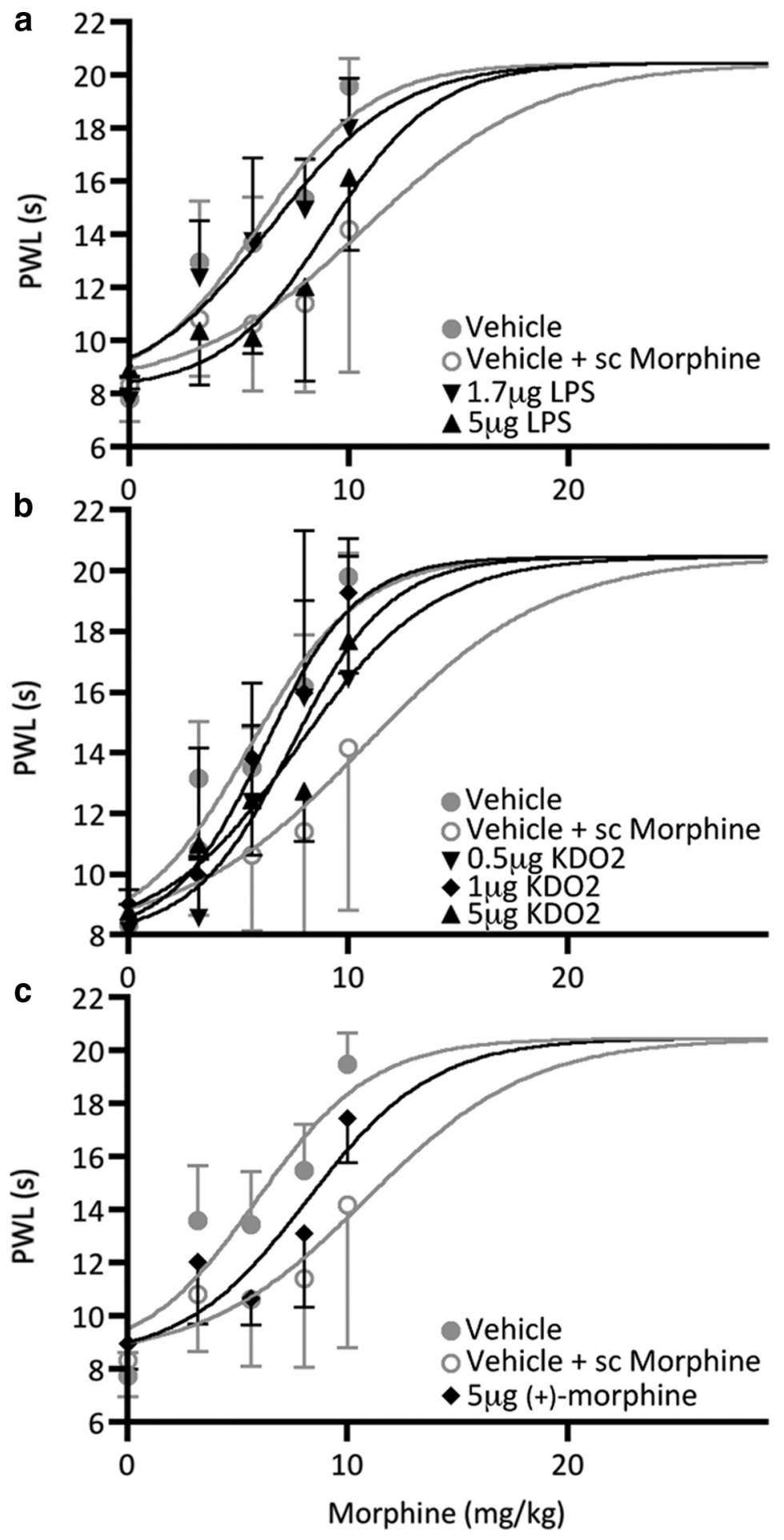

Figure 5. PWL represented as mean $D_{50} \pm 95 \% \mathrm{Cl}$ as a function of cumulative injections of morphine in rats treated with (a) vIPAG Vehicle $(n=8)$, vIPAG Vehicle + sc Morphine $(n=7)$, and vIPAG LPS $(1.7 \mu \mathrm{g}, n=7$ or $5 \mu \mathrm{g}, n=6),(\boldsymbol{b})$ vIPAG Vehicle $(n=10)$, vIPAG Vehicle + sc Morphine $(n=7)$, and vIPAG KD02 $(0.5 \mu \mathrm{g}, n=5 ; 1 \mu \mathrm{g}, n=3$; or $5 \mu \mathrm{g}, n=6)$ and (c) vIPAG Vehicle $(n=7)$, vIPAG Vehicle + sc Morphine $(n=7)$, and vIPAG (+)-morphine $(5 \mu \mathrm{g}, n=10)$.

oid receptor inactive antagonist $(+)$-naloxone ( $\mathrm{Wu}$ et al., 2006).

It is now clear that TLR4 activity opposes morphine analgesia. Hutchinson et al. (2010b) provided convincing in vitro, in vivo, and in silico data indicating that TLR4, along with its coreceptor MD-2, binds opioid agonists and antagonists (e.g., morphine and naloxone) in a nonstereoselective fashion with 


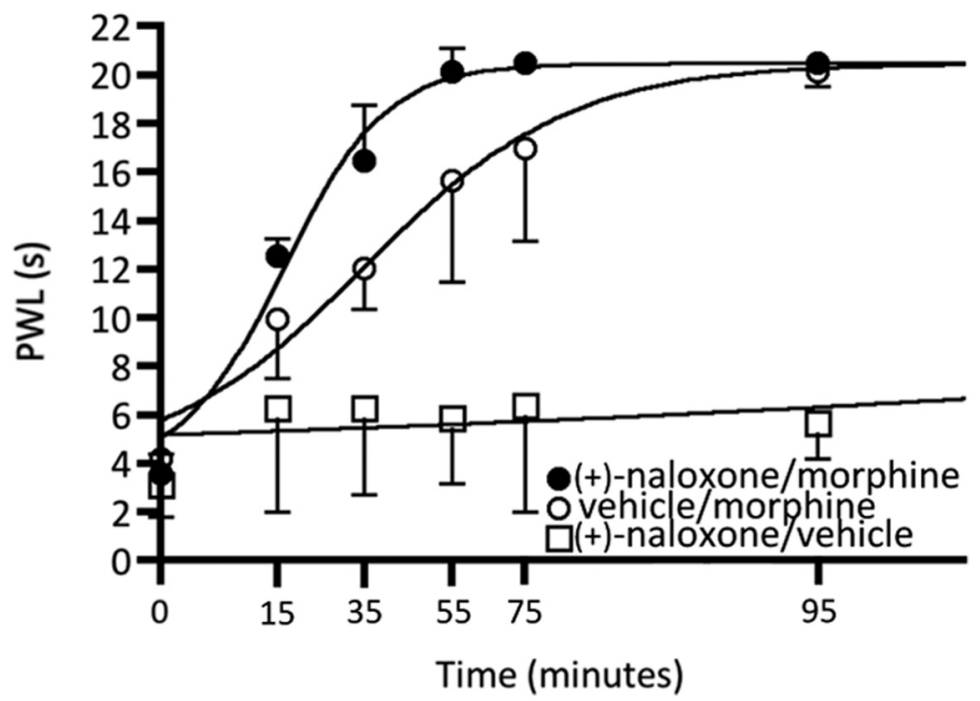

Figure 6. PWL represented as mean $\mathrm{D}_{50} \pm 95 \% \mathrm{Cl}$ across time (minutes) in rats treated with one injection of sc $(+)$-naloxone $(8 \mathrm{mg} / \mathrm{kg})$ and cumulative injections of sc morphine $(n=5)$, one injection of sc vehicle $(1 \mathrm{ml} / \mathrm{kg})$ and cumulative injections of $\mathrm{sc}$ morphine $(n=8)$, and one injection of sc $(+)$-naloxone $(8 \mathrm{mg} / \mathrm{kg})$ and repeated injections of sc vehicle $(n=3)$. All injections were subcutaneous. (+)-naloxone (or vehicle control) was injected immediately after baseline testing (Time 0$)$. Twenty-four hours before PWL testing all animals received an injection of CFA into the hindpaw (200 $\mu \mathrm{l})$.

both the (-)- and (+)-stereoisomers affecting the TLR4 signaling cascade in a manner that maintains their agonistic and antagonistic properties.

Functionally, animals that receive TLR4 antagonism, as well as TLR4 knock-out mice, exhibit increased responsiveness to the analgesic properties of acute morphine administration (Watkins et al., 2009). In addition, systemic (+)-naloxone prevents the development of tolerance to systemic (-)-morphine (Hutchinson et al., 2010b). Here we establish the vlPAG as a key CNS locus through which TLR4 signaling mediates morphine tolerance. Importantly, we show dense and homogeneous expression of MD-2 across the rostrocaudal extent of the vlPAG, and report that MD-2 immunoreactivity is significantly greater in the vlPAG compared with the dIPAG, a subregion of the PAG not implicated in morphine tolerance development (Tortorici et al., 1999). Further, vlPAG microinfusions of the TLR4 competitive antagonist LPS-RS dose dependently eliminated the development of morphine tolerance to subcutaneous morphine. Here, we further demonstrate that intra-vlPAG administration of the opioid receptor inactive form of naloxone, (+)-naloxone, which blocks TLR4 signaling in vitro, completely abolished the development of tolerance to systemic morphine (Hutchinson et al., 2010b). These results suggest that vlPAG TLR4 is necessary for the development of morphine tolerance. Last, we show that vlPAG microinfusions of several TLR4 agonists induced a naive tolerance to subsequent challenge doses of morphine. vlPAG infusions of the prototypical TLR4 agonist LPS, the synthetic TLR4 agonist KDO2, and the opioid receptor inactive form of morphine, $(+)$-morphine, in the absence of systemic (-)-morphine, all resulted in a tolerance to subsequent doses of $(-)$-morphine, indicating that activation of vlPAG TLR4 is sufficient to induce tolerance.

\section{TLR4 opposes acute antihyperalgesia}

Our results demonstrating that acute inhibition of TLR4 potentiated morphine analgesia in a model of persistent pain have exciting implications for the clinical treatment of chronic pain. This work complements previous work demonstrating that TLR4 agonism enhances pain, and that TLR4 antagonism potentiates the analgesic efficacy of morphine in the absence of pain (Hutchinson et al., 2010b; Lewis et al., 2013). Further, our results support the finding that the opioid receptor inactive, $(+)$ stereoisomer of naloxone attenuates pain in the absence of morphine (Lewis et al., 2012; Li et al., 2013). (+)-Naloxone has been demonstrated to be blood-brain barrier permeable with pharmacokinetic properties similar to its widely prescribed stereoisomer $(-)$-naloxone, indicating that (+)naloxone could readily translate to clinical applications (Watkins et al., 2009; Lewis et al., 2012). Although morphine is among the most effective analgesics available, chronic morphine treatment leads to a myriad of negative side effects including tolerance. Morphine tolerance is particularly problematic as it is often addressed by increasing the dose of morphine prescribed. Dose escalation leads to increased risk of developing additional negative side effects, including anti-analgesia, addiction, withdrawal, and respiratory depression, and is not always sufficient to overcome tolerance and reinstate analgesic efficacy (Trescot et al., 2006, 2008). Interestingly, the proinflammatory glial response to opioids has been implicated in many of the negative side effects associated with opioid treatment (e.g., withdrawal, reward, dependence, respiratory depression, and tolerance; Hutchinson et al., 2009; Watkins et al., 2009). As $>90 \%$ of chronic pain sufferers are treated with opioids, including morphine, these data have exciting implications for pain management (Watkins et al., 2005; Trescot et al., 2006). Indeed, decreasing the dose of morphine prescribed by coadministration of (+)-naloxone could enhance morphine analgesia and prevent negative consequences of opioid therapy including tolerance development.

\section{References}

Basbaum AI, Clanton CH, Fields HL (1978) Three bulbospinal pathways from the rostral medulla of the cat: an autoradiographic study of pain modulating systems. J Comp Neurol 178:209-224. CrossRef Medline

Bobeck EN, Haseman RA, Hong D, Ingram SL, Morgan MM (2012) Differential development of antinociceptive tolerance to morphine and fentanyl is not linked to efficacy in the ventrolateral periaqueductal gray of the rat. J Pain 13:799-807. CrossRef Medline

Castaño A, Herrera AJ, Cano J, Machado A (2002) The degenerative effect of a single intranigral injection of LPS on the dopaminergic system is prevented by dexamethasone, and not mimicked by rh-TNF-alpha, IL-1beta and IFN-gamma. J Neurochem 81:150-157. CrossRef Medline

Colburn RW, Rickman AJ, DeLeo JA (1999) The effect of site and type of nerve injury on spinal glial activation and neuropathic pain behavior. Exp Neurol 157:289-304. CrossRef Medline

Commons KG, van Bockstaele EJ, Pfaff DW (1999) Frequent colocalization of mu opioid and NMDA-type glutamate receptors at postsynaptic sites in periaqueductal gray neurons. J Comp Neurol 408:549-559. CrossRef Medline

Commons KG, Aicher SA, Kow LM, Pfaff DW (2000) Presynaptic and postsynaptic relations of mu-opioid receptors to gamma-aminobutyric acidimmunoreactive and medullary-projecting periaqueductal gray neurons. J Comp Neurol 419:532-542. CrossRef Medline

Cui Y, Liao XX, Liu W, Guo RX, Wu ZZ, Zhao CM, Chen PX, Feng JQ (2008) A novel role of minocycline: attenuating morphine antinociceptive tolerance by inhibition of $\mathrm{p} 38$ MAPK in the activated spinal microglia. Brain Behav Immun 22:114-123. CrossRef Medline

Eidson LN, Murphy AZ (2013) Persistent peripheral inflammation attenuates morphine-induced periaqueductal gray glial cell activation and analgesic tolerance in the male rat. J Pain 14:393-404. CrossRef Medline 
Hameed H, Hameed M, Christo PJ (2010) The effect of morphine on glial cells as a potential therapeutic target for pharmacological development of analgesic drugs. Curr Pain Headache Rep 14:96-104. CrossRef Medline

Hammer GD, Kapp BS (1986) The effects of naloxone administered into the periaqueductal gray on shock-elicited freezing behavior in the rat. Behav Neural Biol 46:189-195. CrossRef Medline

Hargreaves K, Dubner R, Brown F, Flores C, Joris J (1988) A new and sensitive method for measuring thermal nociception in cutaneous hyperalgesia. Pain 32:77-88. CrossRef Medline

Hernández-Romero MC, Argüelles S, Villarán RF, de Pablos RM, DelgadoCortés MJ, Santiago M, Herrera AJ, Cano J, Machado A (2008) Simvastatin prevents the inflammatory process and the dopaminergic degeneration induced by the intranigral injection of lipopolysaccharide. J Neurochem 105:445-459. CrossRef Medline

Hutchinson MR, Bland ST, Johnson KW, Rice KC, Maier SF, Watkins LR (2007) Opioid-induced glial activation: mechanisms of activation and implications for opioid analgesia, dependence, and reward. ScientificWorldJournal 7:98-111. CrossRef

Hutchinson MR, Coats BD, Lewis SS, Zhang Y, Sprunger DB, Rezvani N, Baker EM, Jekich BM, Wieseler JL, Somogyi AA, Martin D, Poole S, Judd CM, Maier SF, Watkins LR (2008a) Proinflammatory cytokines oppose opioid-induced acute and chronic analgesia. Brain Behav Immun 22: 1178-1189. CrossRef Medline

Hutchinson MR, Zhang Y, Brown K, Coats BD, Shridhar M, Sholar PW, Patel SJ, Crysdale NY, Harrison JA, Maier SF, Rice KC, Watkins LR (2008b) Non-stereoselective reversal of neuropathic pain by naloxone and naltrexone: involvement of toll-like receptor 4 (TLR4). Eur J Neurosci 28: 20-29. CrossRef Medline

Hutchinson MR, Lewis SS, Coats BD, Skyba DA, Crysdale NY, Berkelhammer DL, Brzeski A, Northcutt A, Vietz CM, Judd CM, Maier SF, Watkins LR, Johnson KW (2009) Reduction of opioid withdrawal and potentiation of acute opioid analgesia by systemic AV411 (ibudilast). Brain Behav Immun 23:240-250. CrossRef Medline

Hutchinson MR, Lewis SS, Coats BD, Rezvani N, Zhang Y, Wieseler JL, Somogyi AA, Yin H, Maier SF, Rice KC, Watkins LR (2010a) Possible involvement of toll-like receptor 4/myeloid differentiation factor-2 activity of opioid inactive isomers causes spinal proinflammation and related behavioral consequences. Neuroscience 167:880-893. CrossRef Medline

Hutchinson MR, Zhang Y, Shridhar M, Evans JH, Buchanan MM, Zhao TX, Slivka PF, Coats BD, Rezvani N, Wieseler J, Hughes TS, Landgraf KE, Chan S, Fong S, Phipps S, Falke JJ, Leinwand LA, Maier SF, Yin H, Rice $\mathrm{KC}$, et al. (2010b) Evidence that opioids may have toll-like receptor 4 and MD-2 effects. Brain Behav Immun 24:83-95. CrossRef Medline

Johnston IN, Milligan ED, Wieseler-Frank J, Frank MG, Zapata V, Campisi J, Langer S, Martin D, Green P, Fleshner M, Leinwand L, Maier SF, Watkins LR (2004) A role for proinflammatory cytokines and fractalkine in analgesia, tolerance, and subsequent pain facilitation induced by chronic intrathecal morphine. J Neurosci 24:7353-7365. CrossRef Medline

Jou I, Lee JH, Park SY, Yoon HJ, Joe EH, Park EJ (2006) Gangliosides trigger inflammatory responses via TLR4 in brain glia. Am J Pathol 168:16191630. CrossRef Medline

Juni A, Klein G, Pintar JE, Kest B (2007) Nociception increases during opioid infusion in opioid receptor triple knock-out mice. Neuroscience 147: 439-444. CrossRef Medline

Kalyuzhny AE, Arvidsson U, Wu W, Wessendorf MW (1996) mu-Opioid and delta-opioid receptors are expressed in brainstem antinociceptive circuits: studies using immunocytochemistry and retrograde tracttracing. J Neurosci 16:6490-6503. Medline

Kleibeuker W, Ledeboer A, Eijkelkamp N, Watkins LR, Maier SF, Zijlstra J, Heijnen CJ, Kavelaars A (2007) A role for G protein-coupled receptor kinase 2 in mechanical allodynia. Eur J Neurosci 25:1696-1704. CrossRef Medline

Lane DA, Patel PA, Morgan MM (2005) Evidence for an intrinsic mechanism of antinociceptive tolerance within the ventrolateral periaqueductal gray of rats. Neuroscience 135:227-234. CrossRef Medline

LaPrairie JL, Murphy AZ (2009) Neonatal injury alters adult pain sensitivity by increasing opioid tone in the periaqueductal gray. Front Behav Neurosci 3:31. Medline

Lehnardt S, Massillon L, Follett P, Jensen FE, Ratan R, Rosenberg PA, Volpe JJ, Vartanian T (2003) Activation of innate immunity in the CNS triggers neurodegeneration through a Toll-like receptor 4-dependent pathway. Proc Natl Acad Sci U S A 100:8514-8519. CrossRef Medline
Lewis ME, Khachaturian H, Schäfer MK, Watson SJ (1986) Anatomical approaches to the study of neuropeptides and related mRNA in the central nervous system. Res Publ Assoc Res Nerv Ment Dis 64:79-109. Medline

Lewis SS, Hutchinson MR, Rezvani N, Loram LC, Zhang Y, Maier SF, Rice KC, Watkins LR (2010) Evidence that intrathecal morphine-3glucuronide may cause pain enhancement via toll-like receptor 4/MD-2 and interleukin-1beta. Neuroscience 165:569-583. CrossRef Medline

Lewis SS, Loram LC, Hutchinson MR, Li CM, Zhang Y, Maier SF, Huang Y, Rice KC, Watkins LR (2012) (+)-Naloxone, an opioid-inactive toll-like receptor 4 signaling inhibitor, reverses multiple models of chronic neuropathic pain in rats. J Pain 13:498-506. CrossRef Medline

Lewis SS, Hutchinson MR, Zhang Y, Hund DK, Maier SF, Rice KC, Watkins LR (2013) Glucuronic acid and the ethanol metabolite ethyl-glucuronide cause tolllike receptor 4 activation and enhanced pain. Brain Behav Immun 30:24-32. CrossRef Medline

Li X, Wang XW, Feng XM, Zhou WJ, Wang YQ, Mao-Ying QL (2013) Stage-dependent anti-allodynic effects of intrathecal Toll-like receptor 4 antagonists in a rat model of cancer induced bone pain. J Physiol Sci 63:203-209. CrossRef Medline

Loyd DR, Murphy AZ (2006) Sex differences in the anatomical and functional organization of the periaqueductal gray-rostral ventromedial medullary pathway in the rat: a potential circuit mediating the sexually dimorphic actions of morphine. J Comp Neurol 496:723-738. CrossRef Medline

Loyd DR, Morgan MM, Murphy AZ (2007) Morphine preferentially activates the periaqueductal gray-rostral ventromedial medullary pathway in the male rat: a potential mechanism for sex differences in antinociception. Neuroscience 147:456-468. CrossRef Medline

Loyd DR, Morgan MM, Murphy AZ (2008a) Sexually dimorphic activation of the periaqueductal gray-rostral ventromedial medullary circuit during the development of tolerance to morphine in the rat. Eur J Neurosci 27:1517-1524. CrossRef Medline

Loyd DR, Wang X, Murphy AZ (2008b) Sex differences in micro-opioid receptor expression in the rat midbrain periaqueductal gray are essential for eliciting sex differences in morphine analgesia. J Neurosci 28:1400714017. CrossRef Medline

Mansour A, Lewis ME, Khachaturian H, Akil H, Watson SJ (1986) Pharmacological and anatomical evidence of selective mu, delta, and kappa opioid receptor binding in rat brain. Brain Res 399:69-79. CrossRef Medline

Mansour A, Khachaturian H, Lewis ME, Akil H, Watson SJ (1987) Autoradiographic differentiation of $\mathrm{mu}$, delta, and kappa opioid receptors in the rat forebrain and midbrain. J Neurosci 7:2445-2464. Medline

Mauriño R, Machado A, Santiago M (2010) Effect of in vivo striatal perfusion of lipopolysaccharide on dopamine metabolites. Neurosci Lett 475 : 121-123. CrossRef Medline

Mika J (2008) Modulation of microglia can attenuate neuropathic pain symptoms and enhance morphine effectiveness. Pharmacol Rep 60:297307. Medline

Morgan MM, Fossum EN, Levine CS, Ingram SL (2006a) Antinociceptive tolerance revealed by cumulative intracranial microinjections of morphine into the periaqueductal gray in the rat. Pharmacol Biochem Behav 85:214-219. CrossRef Medline

Morgan MM, Fossum EN, Stalding BM, King MM (2006b) Morphine antinociceptive potency on chemical, mechanical, and thermal nociceptive tests in the rat. J Pain 7:358-366. CrossRef Medline

Morioka N, Inoue A, Hanada T, Kumagai K, Takeda K, Ikoma K, Hide I, Tamura Y, Shiomi H, Dohi T, Nakata Y (2002) Nitric oxide synergistically potentiates interleukin- 1 beta-induced increase of cyclooxygenase- 2 mRNA levels, resulting in the facilitation of substance $\mathrm{P}$ release from primary afferent neurons: involvement of cGMP-independent mechanisms. Neuropharmacology 43:868-876. CrossRef Medline

Murphy AZ, Hoffman GE (2001) Distribution of gonadal steroid receptorcontaining neurons in the preoptic-periaqueductal gray-brainstem pathway: a potential circuit for the initiation of male sexual behavior. J Comp Neurol 438:191-212. CrossRef Medline

Nichols ML, Lopez Y, Ossipov MH, Bian D, Porreca F (1997) Enhancement of the antiallodynic and antinociceptive efficacy of spinal morphine by antisera to dynorphin A (1-13) or MK-801 in a nerve-ligation model of peripheral neuropathy. Pain 69:317-322. CrossRef Medline

Ogoshi F, Yin HZ, Kuppumbatti Y, Song B, Amindari S, Weiss JH (2005) Tumor necrosis-factor-alpha (TNF-alpha) induces rapid insertion of Ca2+permeable alpha-amino-3-hydroxyl-5-methyl-4-isoxazole-propionate 
(AMPA)/kainate (Ca-A/K) channels in a subset of hippocampal pyramidal neurons. Exp Neurol 193:384-393. CrossRef Medline

Paxinos G, Watson C (1977) The rat brain in stereotaxic coordinates. New York: Academic.

Raghavendra V, Rutkowski MD, DeLeo JA (2002) The role of spinal neuroimmune activation in morphine tolerance/hyperalgesia in neuropathic and sham-operated rats. J Neurosci 22:9980-9989. Medline

Raghavendra V, Tanga F, Rutkowski MD, DeLeo JA (2003) Antihyperalgesic and morphine-sparing actions of propentofylline following peripheral nerve injury in rats: mechanistic implications of spinal glia and proinflammatory cytokines. Pain 104:655-664. CrossRef Medline

Raghavendra V, Tanga FY, DeLeo JA (2004) Attenuation of morphine tolerance, withdrawal-induced hyperalgesia, and associated spinal inflammatory immune responses by propentofylline in rats. Neuropsychopharmacology 29:327-334. CrossRef Medline

Santiago M, Hernández-Romero MC, Machado A, Cano J (2009) Zocor Forte (simvastatin) has a neuroprotective effect against LPS striatal dopaminergic terminals injury, whereas against MPP + does not. Eur J Pharmacol 609:58-64. CrossRef Medline

Song P, Zhao ZQ (2001) The involvement of glial cells in the development of morphine tolerance. Neurosci Res 39:281-286. CrossRef Medline

Stellwagen D, Beattie EC, Seo JY, Malenka RC (2005) Differential regulation of AMPA receptor and GABA receptor trafficking by tumor necrosis factor-alpha. J Neurosci 25:3219-3228. CrossRef Medline

Sweitzer SM, Schubert P, DeLeo JA (2001) Propentofylline, a glial modulating agent, exhibits antiallodynic properties in a rat model of neuropathic pain. J Pharmacol Exp Ther 297:1210-1217. Medline

Tawfik VL, Nutile-McMenemy N, Lacroix-Fralish ML, Deleo JA (2007) Efficacy of propentofylline, a glial modulating agent, on existing mechanical allodynia following peripheral nerve injury. Brain Behav Immun 21:238246. CrossRef Medline

Terashvili M, Wu HE, Moore RM, Harder DR, Tseng LF (2007) (+)Morphine and (-)-morphine stereoselectively attenuate the (-)morphine-produced tail-flick inhibition via the naloxone-sensitive sigma receptor in the ventral periaqueductal gray of the rat. Eur J Pharmacol 571:1-7. CrossRef Medline
Tortorici V, Robbins CS, Morgan MM (1999) Tolerance to the antinociceptive effect of morphine microinjections into the ventral but not lateraldorsal periaqueductal gray of the rat. Behav Neurosci 113:833-839. CrossRef Medline

Tortorici V, Morgan MM, Vanegas H (2001) Tolerance to repeated microinjection of morphine into the periaqueductal gray is associated with changes in the behavior of off- and on-cells in the rostral ventromedial medulla of rats. Pain 89:237-244. CrossRef Medline

Trescot AM, Boswell MV, Atluri SL, Hansen HC, Deer TR, Abdi S, Jasper JF, Singh V, Jordan AE, Johnson BW, Cicala RS, Dunbar EE, Helm S 2nd, Varley KG, Suchdev PK, Swicegood JR, Calodney AK, Ogoke BA, Minore WS, Manchikanti L (2006) Opioid guidelines in the management of chronic non-cancer pain. Pain Physician 9:1-39. Medline

Trescot AM, Glaser SE, Hansen H, Benyamin R, Patel S, Manchikanti L (2008) Effectiveness of opioids in the treatment of chronic non-cancer pain. Pain Physician 11:S181-S200. Medline

Wang H, Wessendorf MW (2002) Mu- and delta-opioid receptor mRNAs are expressed in periaqueductal gray neurons projecting to the rostral ventromedial medulla. Neuroscience 109:619-634. CrossRef Medline

Wang X, Traub RJ, Murphy AZ (2006) Persistent pain model reveals sex difference in morphine potency. Am J Physiol Regul Integr Comp Physiol 291:R300-R306. CrossRef Medline

Watkins LR, Hutchinson MR, Johnston IN, Maier SF (2005) Glia: novel counter-regulators of opioid analgesia. Trends Neurosci 28:661-669. CrossRef Medline

Watkins LR, Hutchinson MR, Rice KC, Maier SF (2009) The "toll" of opioid-induced glial activation: improving the clinical efficacy of opioids by targeting glia. Trends Pharmacol Sci 30:581-591. CrossRef Medline

Wei F, Guo W, Zou S, Ren K, Dubner R (2008) Supraspinal glial-neuronal interactions contribute to descending pain facilitation. J Neurosci 28: 10482-10495. CrossRef Medline

Wu HE, Sun HS, Cheng CW, Terashvili M, Tseng LF (2006) dextroNaloxone or levo-naloxone reverses the attenuation of morphine antinociception induced by lipopolysaccharide in the mouse spinal cord via a non-opioid mechanism. Eur J Neurosci 24:2575-2580. CrossRef Medline 